\title{
THE EFFECT OF TOURIST OBJECTIVE PHOTOS OF TOURIST FESTIVAL ON SPORT TOURISM (ASIAN GAMES) IN PALEMBANG, INDONESIA
}

\author{
Muhammad Juliansyah Putra', Bambang Hermanto ${ }^{2}$, Iwan Sukoco ${ }^{3}$, \\ Suryanto $^{4}$, Bukman Lian ${ }^{5}$ Zulkifli Harahap ${ }^{6}$ \\ Universitas Padjadjaran ${ }^{2,3,4}$,Universitas PGRI Palembang ${ }^{1,5}$ \\ Politeknik Pariwisata Kota Palembang ${ }^{6}$ \\ Juliansyah@univpgri-palembang.ac.id, drbukmanlian@univpgri-palembang.ac.id, \\ zharahap.poltekpar@gmail.com
}

\begin{abstract}
Globalization flows and today's technology and information growth have a significant effect on tourism development. Transportation is also highly influential in Indonesia's growth in tourism, which has an effect on the ease with which potential tourists can search as broadly as possible for information about locations, tourist destinations, tourist objects to be visited using whatever form of transport is available. The city of Palembang is the capital of the province of South Sumatra and the second largest city in Sumatra after Medan. The city of Palembang is also known as Venice of the East in the Western world. The city of Palembang is also known as "Venice of the East" in the Western world. The town of Palembang is generally sometimes referred to as the town of Pempek, but there are several locations that can be visited as well as tourist artifacts in the town. The city of Palembang is also known as Venice of the East in the Western world ("Venice of the East"). The town of Palembang is generally sometimes referred to as the town of Pempek, but there are several locations that can be visited as well as tourist artifacts in the town. Palembang City itself is the oldest city in Indonesia based on the Kedukan Bukit Inscription, a legacy from the Sriwijaya empire, with an age of 1382 when viewed. The city of Palembang today is the hub of the government of the Sriwijaya Kingdom. This research using The history of Palembang, which at that time was the capital of the largest maritime Buddhist kingdom in Southeast Asia, the Srivijaya Empire, which in the 9th century ruled the archipelago and the Malay Peninsula, also made this town known as Bumi Sriwijaya. The town of Palembang is generally sometimes referred to as the town of Pempek, but there are several locations that can be visited as well as tourist artifacts in the town. Palembang City itself is the oldest city in Indonesia based on the Kedukan Bukit Inscription, a legacy from the Sriwijaya empire, with an age of 1382 when viewed. The city of Palembang today is the center of the government of the Kingdom of Sriwijaya. Palembang City has many selling points in the world of tourism, according to Ismail (2012). The numerous tourist destinations on offer are deeply rooted in history, beginning with the heritage of art, music, historical locations, and culinary tours that Indonesians and foreigners are very popular for. Finally this study explores and analyzes the effect on the picture of Palembang City Tourism Objectives of the Tourism Sports Festival as seen from the Evaluation Map and SWOT review of the 18th ASEAN Sports Festival 2018 in Palembang City, Indonesia and could be
\end{abstract}

Keywords: Tourism, Sports Festival, Picture of Tourism Destination, SWOT Review, Evaluation.

Accepted: 15 th of July 2021

Correspondence author: Muhammad Juliansyah Putra, Universitas PGRI Palembang, Indonesia. E-Mail: Juliansyah@univpgri-palembang.ac.id

DOI http://dx.doi.org/10.31851/hon.v4i2.5644

Jurnal Halaman Olahraga Nusantara licensed under a Creative Commons Attribution-ShareAlike 4.0 International License. 
Muhammad Juliansyah Putra, Bambang Hermanto , Iwan Sukoco, Suryanto, Bukman Lian, Zulkifli Harahap, (2021)

The Effect of Tourist Objective Photos of Tourist Festival on Sport Tourism (Asian Games)

\section{INTRODUCTION}

Indonesia has different kinds of tourism potential, both natural tourism and cultural tourism. Indonesia has different ethnic groups, traditions and cultures due to Indonesia's geographical position as a tropical country that produces natural beauty and animals. With a very large area $\mathrm{x}$ and beautiful tourism objects, especially marine tourism objects, the charm of Indonesian nature. The river tourism sector is one of the sectors on which people in coastal areas or river basins can rely, where these tourist artifacts can enhance the well-being and national growth of people. tourism is an integral part of national development which is carried out in a systematic planned, integrated, sustainable and responsible manner, while at the same time providing for the protection of religious values, communitybased culture, environmental sustainability and quality, as well as the protection of religious values, community-based culture, environmental sustainability and quality.

Palembang City deserves to be one of the cities that the tourism sector may claim has a high selling value. Palembang is the capital of the Province of South Sumatra. Geographically, the Musi River divides Palembang City into two parts, namely opposite Ilir in the north and opposite the ulu in the south. There is an Ampera bridge in the center of these two regions, which is an icon of Palembang Region. This provides Palembang City with many advantages, so that the City Government aims to exploit the existing capacity for tourism to enhance the welfare of Palembang City's citizens.

When properly handled, the tourism sector may become an unexpected economic power. The packaging in the tourism presentation must also look enticing and look different. It must be elegantly packaged with the highlighted benefits and branding of an area. The effect of the great economic growth in Indonesia is very clear, as demonstrated by the expansion of international tourism coming to Indonesia in very large numbers. A significant economic turnover helps the population's economy expand rapidly. Local governments must be willing, with so 
Muhammad Juliansyah Putra, Bambang Hermanto , Iwan Sukoco, Suryanto, Bukman Lian, Zulkifli Harahap, (2021)

The Effect of Tourist Objective Photos of Tourist Festival on Sport Tourism (Asian Games)

many visitors, to provide sufficient facilities and amenities to promote the growth of tourism. The government has made numerous concrete steps in its efforts to grow tourism in Indonesia, but the government still faces several obstacles. Infrastructure, communications and transportation are the principal obstacles. Another thing that may impede tourism, apart from these two factors, is the quality of Indonesian tourism products that are still not produced according to market demand.

As reported by (Muljadi, 2012) stakeholders who can take part in tourism development other than the government are the community that Indonesian tourism is targeted at individuals, people and people, so that the core strength of Indonesian tourism is in the hands of people or it is called community-based tourism development. (Community Based Tourism Development) In accordance with the mandate set out in Government Regulation No 50 of 2011 relating to the 2010-2025 National Tourism Master Development Plan, tourism development is carried out by growing the capacity of community resources and raising the awareness and role of the community and universities.

"In line with this the excerpt from the article entitled "The Role of Higher Education in Promoting Tourism Growth" also explains that It takes cooperation from the five key tourism stakeholders called pentahelix, namely academics, business people, government, society and media, to establish a positive development of the tourism sector. In 2019, In 2019, the government itself set a national target, namely the visit of 20 million international tourists with foreign exchange earnings of IDR 280 trillion, the travel of 275 million domestic tourists, an eight percent contribution to GDP, the development of 13 million jobs and the competitiveness of Indonesian tourism. To achieve this goal, out of 10 priority programs, the Ministry of Tourism has identified three major programs, namely digital tourism, tourist village homestays, and air connectivity. Arief Yahya said the role of academics in the production of human capital for tourism is no less significant (HR). To become a government partner to follow up on the ASEAN 
Muhammad Juliansyah Putra, Bambang Hermanto , Iwan Sukoco, Suryanto, Bukman Lian, Zulkifli Harahap, (2021)

The Effect of Tourist Objective Photos of Tourist Festival on Sport Tourism (Asian Games)

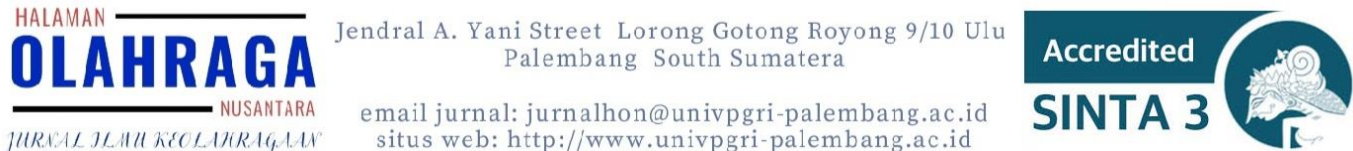

Mutual Recognition Agreement (MRA) as a mutual agreement on the adoption of qualification requirements for tourism professionalism between ASEAN countries (Purnama, 2019), the role of tourism education is currently required.

Strategic collaborations have long been encouraged between the Ministry of Tourism and tourism universities across Indonesia, including in the form of higher education commitments to the growth of tourism in Indonesia. Then as a follow-up to this pledge, the Ministry of Tourism promotes the establishment of technical certification bodies (LSPs) in all tourism universities. Phanayingphaisal and Worawattanaparinya (2020) explain that there are 4 factor that of the effective management guidelines for industrial estate authority to support sustainable growth of the country: planning and policy (1), environmental management (2), Infrastructures and logistics and last knowledge management (4). Strategic collaborations between the Ministry of Tourism and tourism universities across Indonesia, including in the form of higher education commitments to the growth of tourism in Indonesia also need that 4 factor to make sustainable growth of the country in tourism development including in this research on tourism growth in Palembang Region.

Strategic collaborations also ensuring sustainable development in the strategic management of corporations involves the influence of a number of factors characterized by economic, financial, political, social, and psychological indicators, which are tools for monitoring the sustainability of a corporation. Among the many factors that were considered, it is important to consider the factors of strategic management orientation. The calculation of the integral indicator of the influence of all factors on ensuring the sustainable development of a corporation provides a more objective assessment of the course of corporate management processes for ensuring sustainable development (Drobyazko, Okulich-Kazarin, \& Rogovyi, Factors of Influence on the Sustainable Development in the Strategy Management of Corporations, 2019) 
Muhammad Juliansyah Putra, Bambang Hermanto , Iwan Sukoco, Suryanto, Bukman Lian, Zulkifli Harahap, (2021)

The Effect of Tourist Objective Photos of Tourist Festival on Sport Tourism (Asian Games)

The Tourism Sports Festival is one of the aims of introducing seasonal tourist attractions that have a large effect on other tourism events, and perceived importance is a policy built at the moment of reality, as customers carry out the buying process that can have a long-term impact on the next visit decision. The goal of revisiting is to encourage visitors to repeat experiences or revisit a destination (Baker and Crompton in Chung-Hslen Lin Lin) (2012). Marketing is the image of the destination and the image of the destination is the product of any process encountered by visitors since visiting the tourist attraction or flying.

This allows tourists to compare each tourist attraction, resulting in tourist satisfaction or disappointment. Satisfied tourists will build a supportive attitude towards these tourist items, one of which is within a certain amount of time, through endorsing tourist objects or making repeat visits.

In his study, (Suzan, 2012) howed that a good picture of a destination would help visitors feel more happy. He also clarified that it is possible that visitors who regard a destination's reputation positively are able to come back and suggest destinations to others (Okilanda et al., 2021). His analysis also indicates that happiness has a positive effect on post-visiting behavior. The tourist experience element also plays an important role in retaining interest in revisiting, apart from the destination picture. Where the interest in tourism again can be impacted either directly or indirectly by the relative importance of visitors in tourism destinations by the tourist experience factor itself.

\section{Previous Research Studies}

This paper would concentrate on two-way objective cooperation of partners, systematically framed in a traditional matrix of partnerships, reflecting its theoretical contribution. A partnership matrix was created by a panel of experts from academia, practice and the public sector with the goal of disseminating different ways of cooperation between stakeholders, aimed at collectively increasing the right balance required for sustainable tourism growth. (Slivar, Iva : 2018). Without promised tourist happiness, sustainable cultural heritage tourism 
cannot be realized. To this end, this research aims to explore the systemic relationship in the Tigrai, the beginnings of ancient Ethiopian culture, between tourist satisfaction and the aspects of sustainable heritage tourism. The findings of this research help the knowledge among respondents of the sustainability of tourism. In fact, socio-cultural continuity is the best predictor of tourist satisfaction, followed by institutional and economic resilience. An irrelevant indicator was considered to be environmental sustainability. This may be partially because cultural visitors are the bulk of the respondents. Finally this study contains important findings, theoretical and administrative consequences, and future research directions to make a sustainabilty tourism development model in Tigril, Ethiopia (Atsbha \& Satinder, 2019)

\section{Tourism}

Tourism Legislation No. 10 of 2009 describes tourism as a range of forms of tourism activities that is assisted by a variety of services and facilities offered by the city, corporation, government and local government. According to Professor Hunziker and Professor Kraff of Switzerland, "Tourism is the total relationship and the phenomenon linked with the stay of a foreigner at a locality, provided that they do not settle there to exercise a major, permanent or temporary remunerated activity" Which implies that tourism is an overall relationship and phenomenon associated with foreigners living in a region given that they do not settle there for schooling, permanent or temporary activities paid for.

The identification of factors can pave the way of resolving the barriers of women to make them involved in tourism industry. This research can entail human resource development consisting of male and female in the potential tourism business in Bangladesh. Some effective steps are essential to eradicate the negative situations and factors. If government, educational organizations which are offering hospitality education, industry personnel all work as a combined force then the tourism and hospitality sector will boom soon. 
Muhammad Juliansyah Putra, Bambang Hermanto , Iwan Sukoco, Suryanto, Bukman Lian, Zulkifli Harahap, (2021)

The Effect of Tourist Objective Photos of Tourist Festival on Sport Tourism (Asian Games)

\section{Assesment / Evaluation}

In general, (Dunn, 2014) notes that the idea of assessment can be equated with evaluation, assignment of numbers and tests that state efforts in terms of value units to assess policy outcomes. In policy formulation, assessment performs a variety of major roles. Evaluations provide accurate statistics on policy results first and foremost. In this case, the assessment shows the degree to which those aims and objectives have been achieved; the second evaluation also leads to the classification and critique of the principles behind the objectives or objectives; and the third evaluation contributes to the implementation of other policy research approaches, including the formulation of problems and Program Change Guidelines.

Centered on this understanding, there are a range of tasks in the assessment that aim to determine the direction of execution of an action and also as an attempt to evaluate the benefits of a program. "Evaluation is an organic function of administration from the latter, which is a process of expenditure and comparisons of work results that are actually achieved with the results that should be achieved" (Siagian, 2013) says. Too often, corporations also one of solutions to increase the level of competitiveness of their products, increase market capitalization, or create an effective mechanism of production activity (Drobyazko S. , Okulich-Kazarin, V., Goltvenko, \& Marova, 2019)

In the world of today, significant change and globalization require new types of leadership that help organizations achieve their goals and improve their ability. Such leaders who cultivate development, create new ideas, empower and encourage their employees are more responsible for them. They take advantage of the sustainability and success drivers of their companies (Akkaya \& Tabak, 2020) It also means that new leadership concept achieve to improve the assessment process to reach organization goals.

On the basis of these three concepts, it can be inferred that assessment is an attempt to critically evaluate and attach importance to the consequences of the 
Muhammad Juliansyah Putra, Bambang Hermanto, Iwan Sukoco, Suryanto, Bukman Lian, Zulkifli Harahap, (2021)

The Effect of Tourist Objective Photos of Tourist Festival on Sport Tourism (Asian Games)

\section{OLAHRAGA

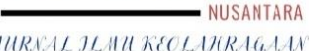 \\ Jendral A. Yani Street Lorong Gotong Royong 9/10 U1 Palembang South Sumatera \\ Accredited \\ email jurnal: jurnalhon@univpgri-palembang.ac.id situs web: http://www.univpgri-palembang.ac.id

previously scheduled task execution. Evaluation can also be used to determine whether the conduct of an action is in line with what was originally intended or not, whether it is not completed, where the weaknesses in the project are such that it can be completely repaired or even halted later. The Joint Committee, meanwhile, maintains that assessment is a formal or frequent analysis of the advantages or uses of an entity (Tayibnapis, 2008). In line with these findings, it is also determined that a feature of strategic management of innovation processes in enterprises is to evaluate the performance indicators of the enterprises.

It may be inferred from the aforementioned opinion that product evaluation is an examination carried out in order to see a program's accomplishment / performance in achieving predetermined objectives. The CIPP evaluation model is more detailed than other evaluation models, according to Eko Putro Widoyoko, since the evaluation object is not just data, but also meaning, feedback, method, and outcomes are included. The beauty of this model is that the decision-making instrument (decision) on the preparation and execution of a program is related to each type of examination. At each evaluation stage, the benefits of the CIPP model include a detailed evaluation format, namely the context, input, method, and product stages.

\section{Tourism in Sports}

Sport-as-play is typically related to the actions of active visitors (participating in athletics) in sports tourism, whereas sports tournaments are usually linked to sportas-play (watching sports). Sport-as-competition and sport-as-play are valid means of conceptualizing sporting practices that we generally think of as games, Ritchie and Adair concluded. Sport is said to be a product of tourism (Ritchie, 2008)

\section{Image Destination}

According to Madden et al. (2016), "destination image is a concept as the expression of all objectives knowledge, prejudices, imagination and emotional thoughts of an individual or group about a particular location" which implies that objective knowledge, bias, imagination and thoughts are the destination image. 
Muhammad Juliansyah Putra, Bambang Hermanto , Iwan Sukoco, Suryanto, Bukman Lian, Zulkifli Harahap, (2021)

The Effect of Tourist Objective Photos of Tourist Festival on Sport Tourism (Asian Games)

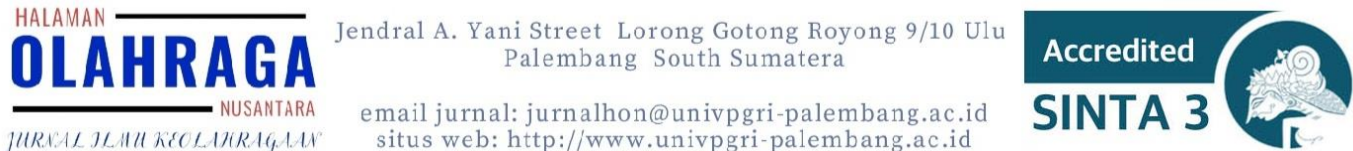

Emotional against a specific location, person or community. According to Echtner and Ritchie in (Kurniawan, 2014) destination image is described as an impression of the experience of a certain region by a location or a person. Picture is a mode of consumption for a marketing destination and market segmentation, affects prospective markets, and plays a role in satisfaction and intention to visit a destination (Croy, 2014). The image of destinations is not always conditioned by experiences or evidence, but can be built into a powerful driving force for visitors to travel to tourist destinations. The picture of the destination based on tourist ratings can differ from individual to individual. In his study, (Suzan, 2012) clarified that the image of the destination consists of the effects of logical evaluations or cognitive images, and emotional evaluations or affective images.

\section{METHOD}

The aim of this research is to identify and evaluate the effect analysis of the Tourism Sports Festival on the picture of the tourist destinations in Palembang Region, Indonesia, based on the form of data and analysis. A qualitative methodology is characterized by Moleong as a research technique that generates descriptive data from individuals and observable behavior in the form of written or oral data.

Analysis An overview of the effect of the Tourism Sports Festival on the picture of tourist destinations in Palembang, Indonesia with SWOT analysis and the CIPP evaluation model is the subject of this study, which includes: context evaluation, input evaluation, process evaluation, product evaluation The analysis of stakeholders is the determinant of the unit of analysis and the collection of informants from this sample, including the detection of all persons and groups who would be impacted or motivated by an action to be carried out and clustered according to the effect of the action to be taken.

SWOT analysis stands for the terms Power (strengths of the company), Limitations, Prospects and Challenges (threats). SWOT analysis entails attempts to define capabilities, vulnerabilities, possibilities, and risks that decide the success of 
Muhammad Juliansyah Putra, Bambang Hermanto, Iwan Sukoco, Suryanto, Bukman Lian, Zulkifli Harahap, (2021)

The Effect of Tourist Objective Photos of Tourist Festival on Sport Tourism (Asian Games)

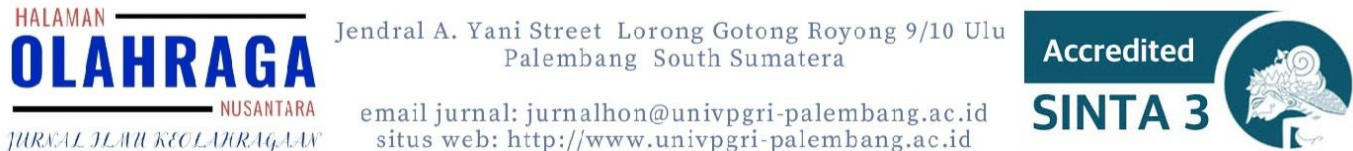

the company combine with dengan Analisis SWOT dan Model Evaluasi CIPP yang meliputi: Context Evaluation, Input Evaluation, Process Evaluation, Product Evaluation. The aim of performing this stakeholder analysis is to establish a pattern of collaboration for the effectiveness of the evacuation to be carried out between the stakeholders involved in this study.

\section{RESULTS AND DISCUSSION}

\section{Tourism (Sport Tourism) in Indonesia}

The growth of tourism is profoundly influenced by the flow of globalization and the development of technologies and information today. Transportation is also highly influential in Indonesia's growth in tourism, and has an effect on the ease with which prospective visitors can search as broadly as possible for information about locations, tourist attractions, tourist items to be visited using whatever mode of transport is available. The tourism industry accounts for 7 percent of overall world exports, or equivalent to US\$ 1.4 trillion, and the tourism sector also contributes 10 percent to the growth in GDP worldwide, with as many as 1,235 million tourists traveling around the world (UNWTO, 2017, p. 4-5). There are also promising developments in Indonesia and the growth of tourism around the world. Where the tourism sector was ranked second in foreign exchange contributions to Indonesia in 2015 after palm oil with a total of 231 trillion rupees, this sector contributed 140 trillion to Indonesia in the previous year, adding 946 trillion to GDP (Gross Domestic Product) and opening up 11 million new jobs (Ratman, 2016, pp. 4-5). The Tourism Sector Development Paradigm as regulated in the 2020-2024 RPJMN is prioritized towards the Quality Tourism Experience with the Main Target :
a. Foreign Exchange \& Value Added Tourism
b. Destination, Industry, Community readiness
c. Human resource capacity
d. Environmental Carrying Capacity
e. Competitive tourism image of the archipelago 
Muhammad Juliansyah Putra, Bambang Hermanto , Iwan Sukoco, Suryanto, Bukman Lian, Zulkifli Harahap, (2021)

The Effect of Tourist Objective Photos of Tourist Festival on Sport Tourism (Asian Games)

\section{OLAHRAGA \\ NUSANTARA email jurnal: jurnalhon@univpgri-palembang.ac.id JURALJHUKROLDIRTALA situsweb: http://www.univpgri-palembang.ac.id \\ Accredited \\ SINTA 3}

\section{Tourism Conditions (Sport Tourism) in Palembang City}

Palembang City is the city of Palembang is the capital of South Sumatra province and the second largest city in Sumatra after Medan (www.palembang.go.id). The history of Palembang, which was once the capital of the largest Buddhist maritime kingdom in Southeast Asia at that time, the Sriwijaya Empire, which dominated the archipelago and the Malay Peninsula in the 9th century also made this city known as "Bumi Sriwijaya". In the Western world, the city of Palembang is also known as Venice of the East ("Venice of the East"). Usually the city of Palembang is often dubbed the city of Pempek, but there are many places that can be visited in the city as well as tourist objects. Palembang City itself is the oldest city in Indonesia, with an age of 1382 when viewed based on the Kedukan Bukit Inscription, a legacy from the Sriwijaya kingdom. The center of government of the Sriwijaya Kingdom is the city of Palembang today. Geographically, Palembang City is located at $2^{\circ} 59^{\prime} 27.99^{\prime}{ }^{\prime}$ LS $104^{\circ} 45^{\prime} 24.24^{\prime}$ ' BT. The area of Palembang City is $358.55 \mathrm{~km} 2$ with an average height of 8 meters above sea level. Palembang's climate is a tropical climate with relative humid winds, wind speeds ranging from $2.3 \mathrm{~km} /$ hour $-4.5 \mathrm{~km} /$ hour. The city temperature ranges from $23.4-31.7^{\circ} \mathrm{C}$. Rainfall per year ranges from 2,000 mm - 3,000 mm. Air humidity ranges from $75-89 \%$ with an average solar radiation of $45 \%$. The land topography is relatively flat and low. Only a small part of the City area has the land located in a rather high place, namely in the northern part of the City.

The Sport Tourism industry is a service industry, and is therefore highly influenced by the quality of services provided. Service quality has been suggested as a key concept for organizations; because research has shown that it is directly related to customer retention rates, and higher profits for the organization. Sport tourism has become a profitable market considering the potential destinations in the world and the diversity of sports. As an economic driver, this sector is developing and managers will start to take advantage of this area, especially because of its contribution to regional development. With the rise of sporting events (such as the 
FIFA World Cup and the Olympics), locally organized and managed small-scale international sporting events are also growing in relevance as a means of promoting local and regional economic development. (PDF) Implementation of Sport Tourism in Exploiting River Potentials in Indonesia

\section{Tourism Sports Festival in Palembang City}

Sports and tourism are currently growing rapidly and are in great demand among young tourists. Recreational sports are sports that lead to movement activities aimed at fun and joy. One of the paradigms of future tourism development based on the 2020-2024 RPJMN is in the field of Quality Tourism Experience with the main targets, namely:

1. Foreign Exchange \& Value Added Tourism

2. Destination, Industry, Community Readiness

3. Human resource capacity

4. Environmental Carrying Capacity

5. Tourism Image Competitiveness of the archipelago

In accordance with the quote from the Director of the Palembang City Tourism Polytechnic, it was stated that "Sport Tourism is Attracting tourists to a specific destination to stay overnight with sport as the motivation for their visit" which means that Sports Tourism attracts tourists to specific Tourism Destinations / Destinations to spend the night with Sports purposes as a motivation for tourists to visit. The Tourism Sports Festival itself can be assumed as a Tourist Sport which consists of:

1. participants / competitors / organizers

2. Suppliers

3. Spectators

4. Visitors to iconic sports facilities and stadiums

Sport Tourism itself can be addressed or given to:

1. Youth sports

2. Adult sports

3. Amateur sports

4. Professional sports

Each of the above events will host major sporting events at least annually so that 


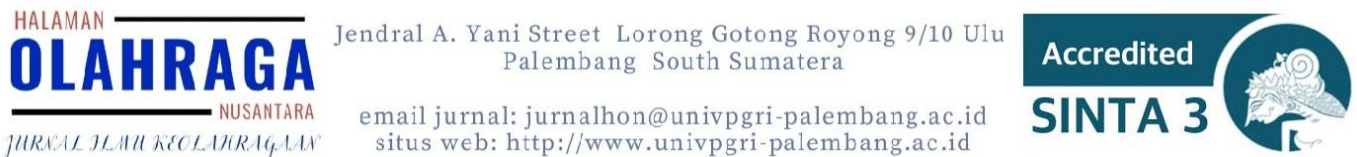

the demand for venues continues to increase.

\section{Example of the Results of the Tourism Sports Festival (Asian Games) in Palembang City}

The implementation of the Tourism Sports Festival in Palembang City on an international scale has a major influence on several other fields, such as the holding of the 18th Asian Games in 2018 (18 August to 02 September 2018) which was held in Jakarta and Palembang has great benefits for the economic sector , transportation and other sectors, especially in the tourism sector, this can be seen from the following data:

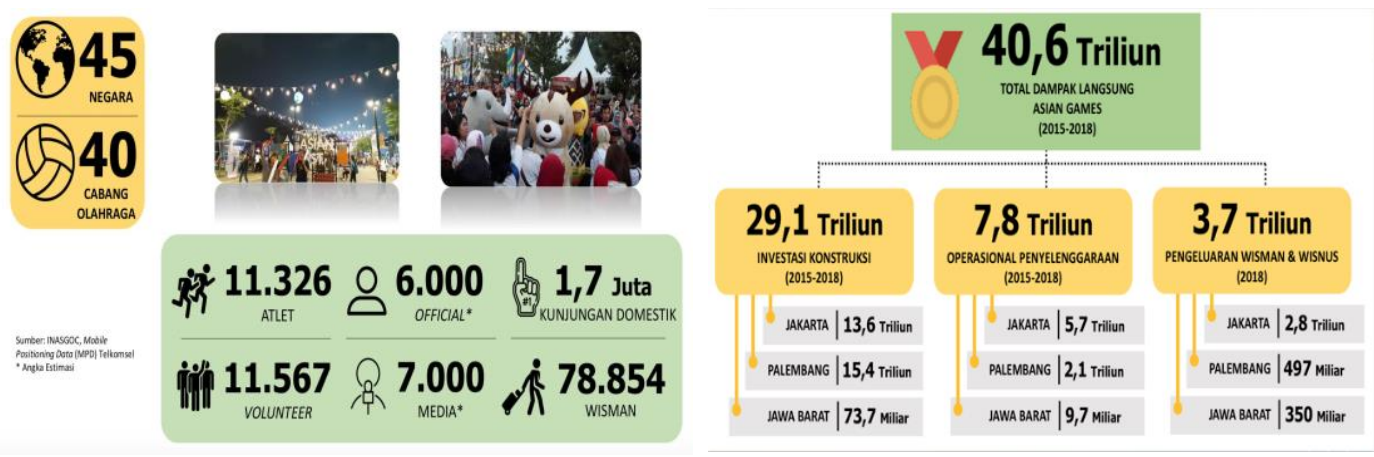

Figure 1. Sectors (Source, Inasgoc Mobile)

In order to ultimately arrive at a summary and decision on the strengths and limitations of the software being assessed, this model assessment attempts to compare the results of different program dimensions with a variety of basic requirements. Here the CIPP evaluation in Tourism Sports Development :

1. Evaluation of Context

The aim of the Tourism Sports Development Program, based on research findings, is to achieve national or international achievements that are observed in accordance with the law. The Tourism Sports Festival is for physical fitness in addition to its nature, as its sports activities can also create their own attraction for visitors to Palembang City. The main objective of this tourism sports festival development program, based on the findings of the researcher, is more for foreign tourists, because it can thus improve the economic sector of Palembang 
City, Palembang City and the State of Indonesia in particular. Then of course, the funding of the local government, not without the assistance of local government intermediaries, the central government and other stakeholders in both the private and non-profit sectors, is the support factor for the progress of the tourism sports growth program in Palembang Region. Palembang is a large tourist area and is famous for its natural beauty, namely the tourism of the River and Ampera Bridge as a feature and the nationally and internationally recognized Palembang City Trademark. Inhibiting the factors or obstacles encountered in the tourist area of Palembang City is the need for special government attention to the fact that tourist areas focused on the development and maintenance of tourist sports require a large amount of money, as well as financial support from the central government.

2. Evaluation of Input.

The input assessment includes plans or strategies for the development of tourism sports programs, the availability of guides for recreational sports and tourism sports, and the availability of budgets for tourism development programs in Palembang City, Indonesia. On the basis of the research findings it can be concluded that the Palembang City Tourism Sports Development Program was implemented by the Palembang City Tourism Office from 2004 onwards, starting with the implementation of the XVI PON held in Palembang City and the Multinational Activities, namely the 18th ASIAN Games held in Palembang City. Palembang and 2018 in Jakarta. The continuation or strategy of the Recreational Sports and Tourism Sports Development Program in Palembang City for the implementation of the Tourism Sports Development Program shall, from year to year, be limited to the budget owned and provided for. We have done several strategies, whether in cooperation with state, national or foreign developers or entrepreneurs, the strategy for tourism growth is not only sport tourism, but must collaborate with the local government so that Palembang City is more global later through the local government to convey to the central 
government to establish a Sport Tourism Policy. Based on the researchers' findings, the tour guide staff in support of the recreational sports development program and tourism sports in Palembang City are the tour guides themselves and the HPI (Indonesian Tour Guides Association) guides that are not sufficient to focus on volunteers for each event at the time of the sports festival event.

3. Evaluating Procedures

Researchers have obtained an assessment process focused on the findings of evaluations, interviews and reports on the facets of the planning of facilities and amenities, promoting the accomplishments and constraints of the growth of tourism and sports tourism in Palembang Region, Indonesia. While the researchers conducted research at the Tourism Office of the City of Palembang and the results of interviews with the Director of the Polytechnic Tourism City of Palembang and the Chancellor of the University of Palembang PGRI (as an academic stakeholder with a study program that contributed to tourism in Palembang City), there were several points obtained in Palembang related to tourism sports. The summary here. A planning for the implementation of the recreational sports development program and tourism sports in Palembang, namely the 18th ASIAN GAMES 2018 event focused in the "Jakabaring Sport City" district, is based on the research findings. There are 10 (ten) sports in the activities held in the Jakabaring Sport City area, namely bowling, rowing (canoeing, rowing, dragon boat), women's football, rollersport (rollerskate and skateboard), takraw football, shooting, climbing. Cliffs, basketball, triathlon, and beach volleyball, which drew 2,459 Asian Games players from 45 countries in 2018. The growth of leisure sports and tourism sports in the Mandeh Integrated Maritime Region has advanced as planned, but the sports infrastructure in the Sport City area of Jakabaring has not been adequately maintained and maintained to the fullest degree possible in order to sustain other programs. The government budget, the infrastructure in Palembang City, Indonesia, the workers in the Palembang City Area, Indonesia and the support 
of the local community are the supporting factors for the success of the tourism growth program and tourism sports in Palembang City, Indonesia. The support anticipated is not only in the form of funding, but also in the form of moral support in the form of promotion, support and maintenance of the facilities and amenities of Palembang City Tourism in general and of the Jakabar Sport City Region in particular.

4. Service Evaluation

Product Evaluation of program goals in this study, where the core of tourism development and tourism sports is a resource that supports tourism development programs and Palembang City tourism sports. Palembang City Tourism Polytechnic and the Chancellor of the University of Palembang PGRI (as partners in the academic sector of study programs that lead to tourism in Palembang City. The aims of the tourism growth program and tourism sports in Palembang City are obvious based on the results of researchers so that people can come and visit the city. Palembang. Then it is also clear that the essence of sports, achievements immediately speak about tourism and accomplishments, now at the national or international level later, there will be an assessment of the best tourism that will be rewarded, which will have an effect on the election of Palembang City in the Indonesia Tourism Charm SAPTA Award 2019, namely 1st place for 2 categories, namely the Tourism Promotion.

\section{CONCLUSION}

The challenge to the activities of this festival is due to the fact that human resources are already poor and uneven, and it is important to provide feedback or socialization later on initiatives and activity plans that will be carried out on a wide scale, both (national and international). In order to have a familiar spirit in leading visitors who attend and engage in the sports festival and visits to tourism attractions in Palembang District, tour guides have to be able to learn foreign languages and regional languages. 
The growth of sports tourism in Palembang City is another challenge, there is insufficient capital to help partners / the tourism sector in the procurement of tourism support equipment, both sports tourism and other tourist attractions, there is no government assistance to provide such support facilities. The restricted access to internet facilities, which results in obstructed contact and events, is then the thing that becomes a barrier.

Based on the review of the CIPP Model Assessment and SWOT analysis, it can be argued that the future production of the Palembang Sports Festival has a very positive effect for Study on the Views of Palembang City Tourist Destinations but its also has numerous problems that make it difficult for Palembang to use this potential and positive effect to be a bring Palembang City Tourism to get reward like this :

1. Tourism as a focus field for Palembang City Growth

2. In 2019, Palembang City won the SAPTA PESONA award for the category of Digital Tourism Promotion and the Most Successful Destination for Halal Tourism.

3. The introduction of the Tourist Sports Festival has had a very positive effect on the reputation of tourist destinations in Palembang Region.

4. The introduction of the Tourism Sports Festival has had a very positive impact, directly or indirectly at the national level, on all relevant industries.

Problems and hurdles emerging from the introduction of the Palembang City Tourism Sports Festival Understanding of Tourist Destinations such as :

1. People who have not fully supported sports tourism event activities need awareness to maintain sports tourism facilities after the event is completed.

2. Lack of government attention to periodically maintaining existing tourism sports facilities

3. The capacity of experts in the tourism sector in Palembang City is still very minimal

In addition to these benefits, the CIPP appraisal model, on the one hand, still has drawbacks, including the use of this model in the field of research. The viability of Palembang City's sports tourism. 


\section{REFERENCES}

A.J., M. (2012). Travel and Tourism. Jakarta: PT Raja Grafindo Persada.

Akkaya, \& Tabak. (2020). The Link between Organizational Agility and Leadership: Research in Science Parks . Academy of Strategic Management Journal, 19(1), https://www.abacademies.org/articles/the-link-betweenorganizational-agili.

Atsbha, G. A., \& Satinder, K. (2019), the institutional relationship between tourist satisfaction and the growth of sustainable heritage tourism . Tigrai, Ethiopian.

Croy, W. G. (2014). The lord of the rings, new zealand, and tourism. New zealand: image building with film.

Drobyazko, S., Okulich-Kazarin, V., \& Rogovyi, A. G. (2019). Factors of Influence on the Sustainable Development in the Strategy Management of Corporations. Academy of Strategic Management Journal, 6. Diambil kembali dari Drobyazko, S.,Okulich-Kazarin, V.,Rogovyi,A., Goltvenko, O., Marova, S. (2019) "Factors of Influence on the Sustainable Development in the Strategy Management of Corporations" Academy of Strategic Management Journal Vol 18 Issue 6. retrieved from https://.

Drobyazko, S., Okulich-Kazarin, V., R., Goltvenko, O., \& Marova, S. (2019, Juni 18). Factors of Influence on the Sustainable Development in the Strategy Management of Corporations. Academy of Strategic Management, 18(6).

Dunn, W. N. (2014). Public Policy Analysis. England: Pearson Education Limited.

Kurniawan, C. J. (2014). Descriptive Study of Destination Image in Malang City According to Surabaya Tourist Perspective. Student Scientific Journal, 3(2).

Muljadi, A. (2012). Travel and Tourism. Jakarta: PT Raja Grafindo Persada.

Okilanda, A., Dlis, F., Humaid, H., Putra, D. D., Arisman, A., \& Muslimin, M. (2021). Defense Warm-Up Exercise Material for 13-Age Athlete Using Video Technology in Covid-19 Era. International Journal of Human Movement and Sports Sciences, 9(4), 629-634. https://doi.org/10.13189/saj.2021.090404

Purnama, H. (2019, Oktober 29). Diambil kembali dari https:/venuemagz.com: https:/venuemagz.com/event/the role of universities-in-supporting-tourismdevelopment/accessed 
Muhammad Juliansyah Putra, Bambang Hermanto , Iwan Sukoco, Suryanto, Bukman Lian, Zulkifli Harahap, (2021)

The Effect of Tourist Objective Photos of Tourist Festival on Sport Tourism (Asian Games)

Ritchie, D. A. (2008). Sport Tourism: Interrelationship, Impacts and Issues. USA: Multilingual Matters Ltd. USA: Multilingual Matters Ltd.

Siagian. (2013). Manajemen Sumber Daya Manusia. Jakarta: Bumi Aksara.

Suzan, C. (2012). The effects on visitor happiness and commitment of the picture of destination, the case of copadia. The case of copadia.

Tayibnapis. (2008). Evaluasi Program dan Instrumen Evaluasi. Jakarta: Rineka Cipta. 